\title{
Madhyamakāvatāra-kārikā Chapter 6
}

\section{Li Xuezhu}

(C) The Author(s) 2014. This article is published with open access at Springerlink.com

\begin{abstract}
The present paper provides a critical edition of basic verses of Madhyamakāvatāra chapter 6 . The verses are extracted from the Sanskrit manuscript of the Madhyamakāvatārabhāṣya preserved at Potala Palace. The Madhyamakāvatāra is one of Candrakīrti's major works and clearly establishes his own doctrinal position. Chapter 6 (about two-thirds of the entire text) contains most important doctrinal discussions of the work.
\end{abstract}

Keywords Madhyamakāvatāra · Candrakīrti · Emptiness · Two truths · Prajñāpāramita $\cdot$ Dharmanairātmya $\cdot$ Pudgalanairātmya

\section{Abbreviations and Signs}

add. added in

AKU Amṛtakaṇikoddyotanibandha = Arryamañjuśrīnāmasamgīti with Amṛtakaṇikāțippaṇi by Bhikṣu Raviśrījñāna and Amṛtakaṇikodyota-nibandha (sic) of Vibhüticandra, edited by Banarsi Lal (Bibliotheca Indo-Tibetica 30), Sarnath: Central Institute of Higher Tibetan Studies, 1994

cf. confer

BCAP Bodhicaryāvatārapañjikā = Bodhicaryāvatāra of Śāntideva with the Commentary Pañjikā of Prajñākaramati, edited by P.L. Vaidya (Buddhist Sanskrit Texts 12), Darbhanga: Mithila Institute, 1960

em. emended

LT Lakșaṇațīka Sanskrit Notes on the Madhyamakāvatārabhāșya Chaper VI, edited by Yonezawa Yoshiyasu, Journal of Naritasan Institute for Buddhist Studies No.36, Naritasan Shinshoji, 2013

Ms manuscript

n.e. no equivalent in

L. Xuezhu ( $\square)$

China Tibetology Research Center, 131 Beishihuan Donglu, Beijing Post No. 100101, China e-mail: mati9017@gmail.com 
Pras Prasannapadā = Mūlamadhyamakakārikās de Nāgārjuna avec la Prasannapadā Commentairede Candrakīrti, edited by Louis de la Vallée Poussin, Bibliotheca Buddhica IV, St. Petersburg, 1903-1913

SS Subhāṣitasamgraha, edited by Cecil Bendall, M.A., Louvain, 1905

T Tibetan translation

* virāma

\{\} contain deleted akșara(s)

$<>\quad$ contain emendational addition

[ ] unclear/damaged akșara(s) in the manuscript

«» Akșara(s) inserted by the scribe in the manuscript

$\{\{\}\} A k s a r a(s)$ cancelled by the scribe in the manuscript illegible part(s) of an akșara

.. one illegible akșara

/// A broken point at the right/left end of the palm leaf

\section{Introduction}

The existence of a Sanskrit manuscript of Candrakīrti's Madhyamakāvatārabhāṣya in the Sanskrit manuscript collection of the Potala Palacein Lhasa was first reported by Luo Zhao. ${ }^{1}$ The manuscript was later microfilmed. At present, we are only able to access the manuscript through the microfilm copy preserved at the China Tibetology Research Centre (CTRC), Beijing. According to Luo Zhao's report, the palm-leaf manuscript consists of 97 folia in total, of which the second folio is missing. The palm leaves measure $56.1 \times 5 \mathrm{~cm}$. Each folio has two string holes and five lines (occasionally four lines). The script is the Nepalese hooked style. The colophon includes no specific information with regard to the date or place of writing, and simply reads: "madhyamakāvatārah ya (sic) samāptah bhāsyatah II II krtir ācāryacandrakīrttipādānām II."

As indicated by the colophon, the manuscript includes the text of both the basic verses $(k \bar{a} r i k \bar{a})$ and their commentary $(b h \bar{a} s y a)$. Research on the manuscript, which has the aim of presenting a critical Sanskrit edition of the entire text, was begun in 2008 as a collaborative project between the CTRC and the IKGA (Institute for the Cultural and Intellectual History of Asia, Austrian Academy of Sciences, Vienna). A critical edition of the first five chapters of the Madhyamakāvatāra and the Madhyamakāvatārabhāṣya will be published soon.

My work on the verses was carried out under the guidance of Prof. Shoryu Katsura, who in 2011 generously invited me to Ryukoku University, Kyoto, as a Numata fellow. Together we read the Madhyamakāvatāra in weekly sessions. The same year, I published a critical edition of the first 97 verses of chapter six in China Tibetology Vol. 18. In 2012 I extracted and edited the remaining verses of chapter six. In the present paper, I present a critical edition of all of the verses as contained in chapter six of our manuscript.

\footnotetext{
${ }^{1}$ A catalogue of the Manuscripts Preserved at the Potala Palace. (Unpublished manuscript) July 1985.
} 
As is well known, chapter six, with 226 verses, makes up about two-thirds of the entire work, which consists of 330 verses in total. Indeed, this chapter presents Candrakīrti's most crucial philosophical viewpoints in the Madhyamakāvatāra. It is divided into the following five sections:

I. Introduction (1-7)

1. Explanation of the Abhimukhī bhūmi and praise of the Prajñāpāramitā $(1-2)$

2. Explanation of dependent origination following Nāgārjuna (3)

3. The proper vessel for understanding emptiness (4-5abc)

4. The merits of understanding emptiness (5d-7)

II. Explanation of dharmanairātmya (8-119)

1. Denial of four types of production $(8 a-b)$

2. Denial of spontaneous production $(8 c-13)$

3. Denial of production from another (14-22)

4. Exposition of the Two Truths (23)

5. Mundane Truth (24-28)

6. Ultimate Truth (29)

7. Denial of production from another from the viewpoint of the Two Truths (30-32)

8. Criticism of the Mind-only Doctrine (33-38)

9. Refutation of the alayavijñāna (39-44)

10. Rejection of the Mind-only Doctrine (45-55)

11. Criticism of the Seed Theory (56-68)

12. Identity of the object and its perception (69-72)

13. Denial of self-perception (73-77)

14. Denial of paratantrasvabhāva (78-83)

15. Clarification of the hidden meaning of the canonical doctrine that teaches the Cittamātra (84-97)

16. Denial of the combination of self-production and production from another (98-103)

17. Establishment of dependent origination (104-116)

18. Revelation through understanding dependent origination (117-119)

III. Explanation of pudgalanairātmya (120-179)

1. The Ego-view as a cause of defilement (120)

2. Inseparability of the Self and the Aggregates (121-125)

3. The Aggregates as different from the Self (126-141)

4. Independence of the Self from the Aggregates (142-145)

5. Denial of pudgala (146-150)

6. Denial of the Self from seven points (151-165)

7. Denial of the intrinsic nature of Possession of the Self (166-170)

8. Opponent's (= Nyāya school) objection (171-172)

9. Refutation of the objection (173-178)

IV. The sixteen kinds of emptiness (179-223)

1. Summary of the classification of emptiness (179-180)

2. Four kinds of emptiness beginning with Internal Emptiness (181-186) 
3. Four kinds of emptiness beginning with Vast Emptiness (187-192)

4. Four kinds of emptiness beginning with Emptiness of Transcendence of Extremes (193-199)

5. Four kinds of emptiness beginning with Emptiness of All Things (200-218)

6. Summarizing the sixteen kinds of emptiness into four (219-223)

V. Conclusion: Qualities of the sixth stage (224-226)

In the section "Explanation of dharmanairātmya," Candrakīti presents his own position on the Two Truths (verses 23-29) and criticizes core Yogācāra doctrines, including the àlayavijñanna, the non-existence of external objects, and self-perception (verses 39-97); in the section "Explanation of pudgalanairātmya," he defends himself against opponents who expect the use of logical argumentation based on real things (verses 171-176). In the section "Explanation of the sixteen kinds of emptiness," he discusses sixteen kinds of emptiness directly based on Ägama and Prajñāpāramitā scriptures (this is in distinction to other Madhyamaka authors).

I am grateful to Prof. Shoryu Katsura for his regular reading sessions, as well as to Dr. Anne MacDonald, Prof. Diwakar Acharya, Prof. Helmut Krasser, Prof. Yusho Wakahara, Prof. Kazunobu Matsuda, Dr. Toru Tomabechi, and Dr. Kazuo Kano for their various suggestions in the process of my work.

Gemination and degemination before/after consonants and avagrahas are not reported in the present edition.

\section{Verses of Chapter 6}

samāhite cetasi saṃsthito 'sau

saṃbuddhadharmābhimukho 'bhimukhyām |

idampratītyodayadṛștatattvah

prajñāvihārāt tunirodham eti || 6.1

ekena pumsākșimatā ${ }^{2}$ yatheșțạ̣

deśam samasto 'ndhagaṇạ sukhena |

ākṛ̣yate tadvad ihākṣihīnān

ādāya dhīr yāti guṇāñ jinatvam || 6.2

dharmān sa gambhīratarān avaiti

yathāgamenāpi ca yuktitaś ca |

tathāryanāgārjunanītitas tān

yathāsthitaprakriyayā bravīmi || 6.3

pṛthagjanatve 'pi niśamya śūnyatāṃ

pramodam antar labhate muhurmuhụ |

prasādajāsrāvilajātalocanas

tanūruhotphullatanuś ca jāyate $\|^{3} 6.4$

\footnotetext{
2 pumsa $\bar{a}^{\circ}$ em. (skyes bu T) : punsa $\bar{a}^{\circ}$ Ms. This verse is quoted in AKU p. 135, tatsāo for pumsā̄o

${ }^{3}$ SS p. 13, ${ }^{\circ}$ srāvanipātalocanah for ${ }^{\circ}$ srāvilajātalocanas (mchi mas mig brlan zhing T);

AKU p.201, ${ }^{\circ}$ sabhute for labhate.
} 
yas tasya saṃbuddhadhiyo 'sti bījạ̣

tattvopadeśasya ca bhājanam sạ̣ |

ākhyeyam asmai paramārthasatyạ̣

tadanvayās tasya guṇā bhavanti $\|^{4} 6.5$

śīlaṃ samādāya sadaiva vartate

dadāti dānaṃ karuṇāṃ ca sevate |

titikṣate tatkuśalạ̣ ca bodhaye

praṇāmayaty eva jagadvimuktaye $\|^{5} 6.6$

sambodhisattveșu karoti gauravam

udāragambhīranaye vicakṣaṇaḥ |

labheta bhūmim muditām janaḥ kramāt

tadarthinaișā $\bar{a}^{6}$ padavī niśāmyatām || 6.7

tebhyas ta eva $^{7}$ na bhavanti kutah parebhyo

dvābhyāṃ na cāpi kuta eva vinaiva hetum |

tasmād dhi tasya bhavane na guṇo 'sti kaścij

jātasya janma punar eva ca naiva yuktam $\|^{8} 6.8$

jātasya janmani punaḥ parikalpyamāne

naivānkurādaya iha prabhavaṃ labheran |

bījasya ca prabhava eva bhaved bhavāntam

tenaiva tasya hi kathạ̣ ca bhaved vināśạ \| 6.9

saṃsthānavarṇarasavīryavipākabhedāḥ

syur nānikurasya tava kāraṇato ${ }^{9}$ vibhinnāḥ |

prāgātmabhāvam avadhūya tadanyarūpam

āpadyate yadi tadāsya katham hi tattvam || 6.10

bījād ananya iha te yadi cānkurah syād

gṛhyeta naiva hi sa bījam ivānkurākhyaḥ |

gṛhyeta vā tad api nāma yathānkuro 'yạ̣

tattvāat ${ }^{10}$ tayor iti na caitad ato 'bhyupeyam ${ }^{11} \| 6.11$

loko 'pi caikyam anayor iti nābhyupaiti

naște 'pi paśyati yatah phalam eșa hetau

tasmān na tattvata idạ̣ na ca lokataś ca

yuktam svato bhavati bhāva iti prakalpam $\|^{12} 6.12$

\footnotetext{
${ }^{4}$ SS p. 13, yat for yas (n.e. T).

5 SS pp. 13-14.

${ }^{6}$ tadarthinaișā em. (de ni don du gnyer bas T) : tadārthanaișā Ms.

7 tebhyas ta eva em. (de nyid de las T) : tebhyaś ca eva Ms.

${ }^{8}$ Pras p. 13.

9 T adds sa bon.

${ }^{10}$ tattvāt. n.e. T.

$11<$ '> bhyupeya $<$ m $>$ em. : bhyupeya Ms.

12 SS p. 16, tu for ca; prakalpyam for prakalpam.
} 
janyasya caiva janakasya ca karmaṇaś ca kartuś ca janmani bhavet svata iṣyamāṇe | aikyam na caikyam anayor iti nābhyupeyam janma svato vihitavistaradoșasakteh ${ }^{13}$ || 6.13

anyat pratītya yadi nāma paro 'bhavișyaj jāyeta tarhi bahulaḥ śikhino 'ndhakāraḥ | sarvasya janma ca bhavet khalu sarvataś ca tulyam paratvam akhile 'janake 'pi yasmāt $\|{ }^{14} 6.14$

śakyam prakartum iti kāryam ato niruktam śaktam yad asya janane sa paro 'pi hetuh | janmaikasantatigatāj janakāe ca tasmāc ${ }^{15^{\circ}}$ chālyañkurasya na tathā ca yavāditaś cet $\|{ }^{16} 6.15$

ișțā yathā na janakā $\overline{1}^{17}$ na ca śaktiyuktā naivaikasantatigatāḥ sadṛśā na caiva | śālyañkurasya yavakesarakimśukādyā no śālibījam api tasya tathā paratvāt || 6.16

asty añkuraś ca na hi bījasamānakālo bījạ̣ kutah paratayāstu vinā paratvam | janmāñkurasya na hisidhyati tena bījāt saṃtyajyatāṃ parata udbhavatīti pakṣah $\|^{18} 6.17$

antadvayasya namanonnamane tulāyā dṛște yathā na khalu naiva samānakāle | syātām tathā janakajanyanirodhajātī yady ekadā tad asad atra vinaikakālam || 6.18 janmonmukhaṃ na sad idạ̣ yadi jāyamānaṃ nāśonmukhạ̣ sad api nāma niruddhyamānam | ișțam tadā katham idam tulayā samānam kartrā vinā janir iyạ̣ na ca yuktarūpā $\|^{19} 6.19$ cakṣurdhiyah svajanakaih khalu cakṣurādyaị samjjñādibhiś ca sahabhāvibhir ekakālaị̣ | anyatvam asti yadi kiṃ bhavanena satyāṃ nāsyāḥ satītvam atha ced vihito 'tra doṣaḥ || 6.20

janyaṃ paraṃ ca janayej janakah sa hetuh sad vātha cāsad ubhayạ̣ vigatadvayaṃ vā |

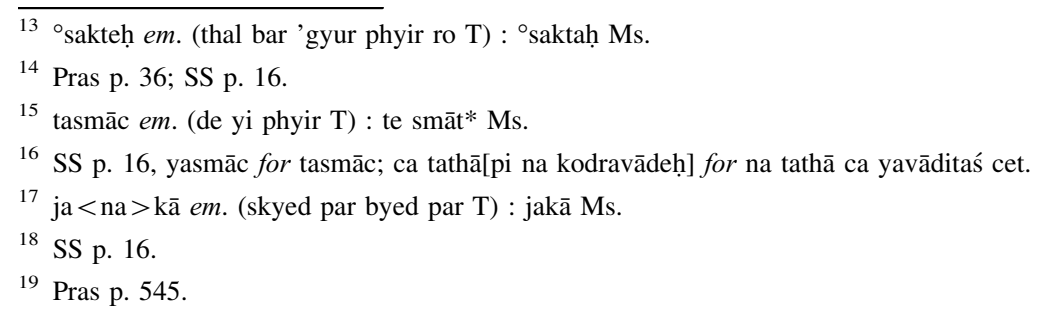


sac cet kim asya janakair asato 'pi kim tair

dvaite 'pi taih kim atha kim vigatadvaye taị $\| 6.21$

yuktyā kim atra khalu varṇitayā kriyeta

lokaḥ $^{20}$ sthitạ svadṛśi yena matah pramāṇam ${ }^{21}$ ।

lokaś ca nāma paratạ parabhāvam eti

tenāsti janma paratạ kim ihopapattyā || 6.22

samyagmṛṣādarśanalabdhabhāvaṃ

rūpadvayam ${ }^{22}$ bibhrati sarvabhāvāḥ |

samyagdrísām yo vișayah ${ }^{23}$ sa tattvam

mṛsāārúsām sạ̣vṛtisatyam uktam $\|^{24} 6.23$

mṛṣādṛ́se 'pi dvividhā matā hi spașțendriyā doṣavadindriyāś ca |

sadindriyajñānam apekṣya mithyā

jñānaṃ matạ̣ doṣavadindriyāṇām || 6.24

vinopaghātena yad indriyāṇāṃ

șaṇnām api grāhyam avaiti lokạ̣ |

satyaṃ hi tal lokata eva śeșạ̣

vikalpitam lokata eva mithyā $\|^{25} 6.25$

ajñānanidrāpracalāyamānais

tīrthair yathāsvaṃ parikalpitā ye |

māyāmarīcyādiṣu kalpitāś ca

teșām atattvam khalu lokato 'pi || 6.26

na bādhate jñānam ataimirāṇāṃ

yathopalabdhis timirekṣaṇāṇām |

tathāmalajñānatiraskṛtānāṃ

dhiyāsti bādho na dhiyo 'malāyāḥ $\|^{26} 6.27$

mohạ̣ svabhāvāvaraṇād dhi saṃvṛtị̣

satyạ̣ tayā khyāti yad eva krtrimam ${ }^{27}$ |

jagāda tat saṃrịtisatyam ity asau

munih padārthaṃ kṛtakañ ca saṃvṛtị ${ }^{28} \|^{29} 6.28$

\footnotetext{
${ }^{20}$ loka $<$ h $>$ sthitah em. (gnas 'jig rten T) : lokasthitah Ms.

21 pramāṇam em. : prāmāṇam Ms.

22 odvayam em. : 'dvayām Ms.

$23{ }^{\circ}$ drúsā $<$ m $>$ yo vi < șa > yah em. (mthong yul gang T) : ${ }^{\circ}$ dṛṣā yo vi $\{\{$ va $\}\}$ ya Ms.

24 BCAP p. 174.

25 BCAP p. 171, evam for eva.

26 BCAP p. 178, 'labdham for ${ }^{\circ}$ labdhis; bādhā for bādho.

27 kṛtrimam em. : kritrimām Ms.

28 Cf. LṬ p. 126, kṛtakan tusaṃvṛtim iti mūlam.

29 BCAP p. 171; AKU p. 135. samvṛtim for samvrụtị.
} 
vikalpitam yat timiraprabhāvāt keśādirūpạ̣ vitathạ̣ tad eva | yenātmanā paśyati śuddhadṛștis tat tattvam ity evam ihāpy avaihi $\|^{30} 6.29$

lokah pramāṇam yadi tattvadarśí syāl loka evety aparaih ${ }^{31}$ kim āryaih | kim āryamārgeṇa bhavec ca kāryaṃ mūụhaḥ pramāṇaṃ na hi nāma yuktạ̣ || 6.30

lokaḥ pramāṇaṃ na hi sarvathātas tattvādhikāre na ca lokabādhā | syāl lokabādhā yadi laukikārtho ${ }^{32}$ lokapratītyaiva nirākriyeta || 6.31 uptvāpi lokaḥ khalu bījamātraṃ bravīti putro janito mayaișạ | uptas taruś ceti paraiti ${ }^{33}$ yasmāj janmānyatas tena na lokato 'pi || 6.32

yato na bījāt paratānkurasya saty ańkure bījam ato na nașțam | eko yato nāsti tato 'pi bījạ̣ saty añkure 'stîti na vācyam eva \| 6.33

svalakșaṇaṃ ced bhavati pratītya tasyāpavāde sati bhāvanāśāt | syāc chūnyatā bhāvavināśahetur yuktam na caitan ${ }^{34}$ na tato 'sti bhāvah $\| 6.34$

arvān் na tattvātmakarūpato 'mī sthitim labhante pravicāryamāṇāḥ | yatah padārthā na tato vicārạ kāryo hi lokavyavahārasatye \| 6.35

tattvādhikāre hi yayaiva yuktyā svasmāt parasmāc ca na janma yuktam | yuktyā tayaiva vyavahārato 'pi na yujyate kena tavāstu janma || 6.36

śūnyāḥ padārthāḥ pratibimbakādyāḥ sāmagryapekșā $\bar{a}^{35}$ na hi na prasiddhāḥ |

\footnotetext{
${ }_{30}$ BCAP p. 176, avehi for avaihi; AKU p. 131, ${ }^{\circ}$ prakāsāât for ${ }^{\circ}$ prabhāvāt; ta[thāiva ta]ttattvam ihāpyavehi for tat tattvam ity evam ihāpy avaihi. p. 150, ${ }^{\circ}$ timiram prakāsaât for ${ }^{\circ}$ timiraprabhāvāt; avehi for avaihi.

31 evety aparaih em. (gzhan gyis T) : evety eparaị Ms (The scribe corrects tyo to tye.)

32 laukikā $\overline{ }^{\circ}$ em. : laukikyā $\bar{a}^{\circ}$ Ms.

33 paraiti em. (rtog T) : parair iti Ms.

34 caitan em. (de ni T) : cetan Ms.

35 oapekșā em. (ltos T) : 'apākșā Ms.
} 
yathā ca śūnyāt pratibimbakādeś

cetas tadākāram upaiti janma || 6.37

evaṃ hi śūnyā api sarvabhāvāḥ

śūnyebhya eva prabhavaṃ ${ }^{36}$ prayānti |

nocchedinas $^{37}$ te na ca śáśvatāś ca

satyadvaye 'pi prakṛter abhāvāt || 6.38

yasmāt svarūpeṇa na tan niruddham

ciram niruddhād api karmaṇo 'tah |

kvacid vinaivālayam asya śakteh

phalam samutpadyata ity avaihi || 6.39

svapnopalabdhān vișayān avetya ${ }^{38}$

bodhe 'pi mūọhasya yathaiva sangah |

saṃjāyate tadvad asatsvabhāvāt

phalạ̣ niruddhād api karmaṇo 'sti || 6.40

tulye 'py asattve vișayasya ${ }^{39}$ yadvat

keśākrtim taimirikah paraiti ${ }^{40}$ ।

na sarvabhāvākṛtim ${ }^{\dot{4}}$ ity avaihi

tathā vipakvān ${ }^{42}$ na punar vipākam $\| 6.41$

ato hi kṛṣnād aśubho vipākaḥ

śubhād vipākaḥ śubha eva dṛștah

śubhāśubhābhāvadhiyaś ca mokṣaś

cintāniṣedhạ̣ phalakarmaṇāṃ ca || 6.42

evaṃ hi gambhīratarān padārthān

na vetti yas tạ prati deśaneyam |

asty ālayah pudgala eva cāsti

skandhā ime vā khalu kevalāś ca $\|^{43} 6.43$

ahaṃ $^{44}$ mamety eva yathā dideśa

satkāyadrșțer vigame 'pi buddhạ̣ |

tathā 'svabhāvān api sarvabhāvān ${ }^{45}$

astīti neyārthatayā dideśa $\|^{46} 6.44$

\footnotetext{
$\overline{36}$ prabhavam em. : prabhavah Ms.

37 nocchedinas em. (chad pa'ang min T) : nocchadenas Ms.

38 T mthong nas for avetya.

$39\{\{$ janake pi $\}\}<$ vișayasya» Ms.

40 paraiti em. : parair iti Ms.

$41 \mathrm{~T}$ dngos po gzhan rnam par for sarvabhāvākritim.

42 vipakvān em. : vipākvān Ms.

43 SS p. 20, dhātavaś for kevalāś.

44 aha $<\mathrm{m}>$ em. (nga T): aha Ms.

45 sarva n.e. T.

46 SS p. 20, 'tayādideśa for ํoyā dideśa.
} 
prajñāvihārī sa hi bodhisattvo

vijñānamātrapratividdhatattvaḥ |

grāhyaṃ vinā grāhakatām apaśyan

vijñānamātraṃ tribhavaṃ ${ }^{47}$ paraiti $\|^{48} 6.45$

yathā tarangā mahato 'mburāśẹ

samīraṇapreraṇayodbhavanti |

tathālayākhyād api sarvabījād

vijñānamātraṃ bhavati svaśakteh $\|^{49} 6.46$

samvidyate 'tah paratantrarūpaṃ ${ }^{50}$

prajñaptisadvastunibandhanam yat |

bāhyam vinā grāhyam udeti sac ca

sarvaprapañcāviṣayasvarūpam $\|^{51} 6.47$

vinaiva bāhyaṃ kva yathāsti cittạ̣

svapne yathā ced idam eva cintyam |

svapne 'pi me naiva hi cittam asti

yadā tadā nāsti nidarśanaṃ te $\|^{52} 6.48$

svapnasya bodhe ${ }^{53}$ smaraṇān mano 'sti

yady astu bāhyo vișayo 'pi tadvat |

yathā mayā dṛștam iti smṛtis te

bāhye 'pi tadvat smṛtisambhavo 'sti $\|^{54} 6.49$

cakșurdhiyah sambhava eva middhe

nāsty asti vai mānasam eva cetạ̣ |

tadākṛtau bāhyatayā niveśah

svapne yathehāpi tathā matạ cet $\|^{55} 6.50$

bāhyo yathā te vișayo na jātạ̣

svapne tathā naiva mano 'pi jātam |

cakṣuś ca cakșurvișayaś ca tajjam

cittạ ca sarvạ̣ trayam apy alīkam $\|^{56} 6.51$

\footnotetext{
47 tribhavaṃ em. (srid gsum T): tribhāvaṃ Ms.

${ }^{48}$ SS p. $18,{ }^{\circ}$ pratibaddhatattvah for ${ }^{\circ}$ pratividdhatattvah.

49 SS p. 18.

${ }^{50}$ parata $<\mathrm{n}>$ tra $^{\circ}$ em. (gzhan gyi dbang T) : paratatra $^{\circ} \mathrm{Ms}$.

${ }^{51}$ SS p. 18, prajñaptisiddhis tu for prajñaptisadvastu ${ }^{\circ}$; yac for sac.

${ }^{52}$ SS p. 18, na for kva (cf. gang du T).

${ }^{53}$ bodhe em. (LT p.131; sad tshe T) : bodhih Ms.

${ }^{54}$ SS p. 19, ${ }^{\circ}$ ranāâtmano for ${ }^{\circ}$ ranān mano; asti for astu; smṛte tu for smrtis te; bāhyeti for bāhye 'pi.

${ }^{55}$ SS p. 19, siddhe for middhe.

${ }^{56}$ SS p. 19, rūpam for cittam (sems T).
} 
śrotrādiśeșam trayam apy ajātam svapne yathehāpi tathā prabodhe | mṛsāa padārthā na tad asti cittạ̣ na gocaraḥ santi ca nendriyāṇi || 6.52

yāvan na bodham labhate 'sti tāvat trayam hi tasyeha yathāprabodhe ${ }^{57}$ | sati prabodhe trayam apy asatyam sa mohanidrākșayatas tathaiva || 6.53

keśākṛtim yāṃ timiraprabhāvād dhiyā yayā vetti ${ }^{58}$ sa taimirākṣah | dvayam hi tadbodham apekșya satyam ${ }^{59}$

spaștārthadṛșter dvayam apy alīkam || 6.54

jñeyaṃ vinā syād yadi nāma buddhis tatkeśadeśānugalocanasya | vitaimirasyāpi ca keśabuddhih syād eva na tv evam ato 'sti naitat || 6.55

dhīśaktipāko 'sti na śuddhadṛșter yatas tato dhīr na hi jāyate 'sya | na jñeyasadbhāvaviyogataś cet tacchaktyabhāvān na hi siddham etat || 6.56

jātasya śakter na hi sambhavo 'sti nājātarūpasya ca śaktir asti | viśeșaṇaṃ nāsti vinā viśeșyaṃ ${ }^{60}$ vandhyāsutasyāpi ca tatprasañgaḥ || 6.57

bhaviṣyatā ced vyapadeśa ișțaḥ śaktị̣ vinā nāsti hi bhāvitāsya $\left.\right|^{61}$ parasparāyāśrayaṇi ${ }^{62}$ ca siddhir asiddhir eveti vadanti santạ || 6.58

niruddhaśakteh paripākatạ̣ syād yady anyaśakteh parasambhavaḥ syāt | santānināṃ tatra mitho 'sti bhedạ̣ sarvasya sarvaprabhavas tatạ syād || 6.59

\footnotetext{
$57 \mathrm{~T}$ ji ltar sad bzhin for yathābodhe.

$58 \mathrm{~T}$ mthong ba for vetti.

59 satya $<$ m $>$ em. : satya Ms.

${ }^{60}$ Pras p. 80, nāstīti for nāsti.

61 Pras p. 82.

${ }^{62} \mathrm{~T}$ phan tshun don la brten pa for parasparāyāśrayaṇī.
} 
santānino yady api tatra bhinnāḥ santānabhedo 'sti hi naiva teșām | tato na doșā $\bar{a}^{63}$ iti sādhyam etat abhedasantānagater ayogāt || 6.60 maitropaguptāśrayiṇo ${ }^{64}$ hi dharmā na hy ekasantānagatāh paratvāt | svalakșaṇenāpi prithak prthag ye te 'py ekasantānagatā na yuktāḥ || 6.61

cakșurdhiyo janma yatạ̣ svaśakter àjāyate 'nantaram eva tasyāḥ | śakteh svavijñānasamāśrayasya rūpīndriyaṃ cakṣur iti pratītị || 6.62

bahir vinā rūpam iha svabījān n̄ilādinirbhāsitayodbhavantīm | vijñaptim akșiprabhavām abuddhvā grāhyạ̣ jano bāhyam avaiti cittāt || 6.63

svapne vinārthāntaram eva rūpaṃ yathā tadākāram udeti cetah | svaśaktipākād iha jāgrato 'pi tathāsti bāhyena vinā manaś cet || 6.64

nīlādinirbhāsam ${ }^{65}$ udeti cetạ svapne yathā mānasam akṣyabhāve | kasmād ihāndhasya tathākșyapāye svabījapākād udayạ̣ na yāti || 6.65

svapne 'sti șașṭhasya hi śaktipāko na jāgrato 'stīti sacet tava syāt | yatheha șaṣthhasya na śaktipākah svapne tathāsann iti kiṃ na vetsi ${ }^{66}$ || 6.66

akṣyor abhāvo 'sya yathā na hetuh svapne 'pi middham na tathaiva ${ }^{67}$ hetuh | svapne 'pi tadrūpam ato 'bhyupeyam cakṣur mṛṣāgocarabodhihetuh || 6.67 yaṃ yạ̣ parīhāram ${ }^{68}$ ayaṃ bravīti tạ̣ tạ̣ pratijñāsamam asya paśyan |

\footnotetext{
63 doṣā em. : doṣa Ms.

64 oāśrayiṇo em. : āśrayeṇo Ms.

65 obhā $<$ sa $>$ m em. (snang ba T) : ' bhām Ms.

$66 \mathrm{~T}$ rigs for vetsi.

$67<$ ta $>$ thaiva em. $(\operatorname{ltar} \mathrm{T})$ : thaiva Ms.

68 parīhāram em. : parīhārām Ms.
} 
nivārayed vādam amuṃ na buddhā vastu kvacin nāma sad ity uśanti ${ }^{69}$ || 6.68 pūrṇāṃ ${ }^{70}$ mahīṃ san̉kalayā $\bar{a}^{71}$ ca yoḡi gurūpadeśād api yat paraiti | tatrāpi paśyet trayam apy ajātam mithyāmanaskāratayopadeśāt || 6.69 yathā 'kṣibuddhau viṣayākṛtis te tathāśubhāyāṃ ${ }^{72}$ manaso yadi syāt | taddeśabuddher itarasya tadvat syād eva bodho na mṛșā ca tat syāt || 6.70 toyaṃ vahantyām api pūyabuddhị pretasya nadyāṃ timirākșatulyā | saṃkṣepatas tv artham amuṃ paraihi jñeyạ̣ yathā nāsty api dhīs tatheti || 6.71 grāhyạ̣ vinā grāhakatāviyuktạ̣ dvayena śūnyaṃ paratantrarūpam ${ }^{73}$ । yady asti kenāsya paraiși sattām agṛhyamāṇam ca sad ity ayuktam || 6.72

tenaiva tasyānubhavo na siddhạ siddhah smṛter uttarakālataś cet | asiddhasiddhyartham asiddham etan nirucyamānaṃ na hi sādhanāya $\| 6.73$

kāmaṃ svasaṃvedanasiddhir astu smartuh smṛter naiva tathāpi yuktā | ajñānasantānajavat ${ }^{74}$ paratvād dhetur $^{75}$ viśeșān api caiṣa hanyāt || 6.74

yenānubhūto vișayas tato 'sya smartuh paratvam na hi me 'sti yasmāt | tato mayā dṛștam iti smṛtih syād eșā ca lokavyavahāranītih || 6.75 tasmāt svasaṃvedanam asti naiva kenānyatantragrahaṇaṃ tava syāt | kartuś ca karmakriyayoś ca naikyam tenaiva tasya grahạ̣ạ̣ na yuktam || 6.76

\footnotetext{
69 uśanti em. (bstan T) : uṣanti Ms.

${ }^{70}$ pūrṇā < ṃ > em. : pūrṇnā Ms.

71 sankkalayā em. (keng rus T) : śaṃkalayā Ms.

72 `śubhāyā $<$ ṃ $>$ em. (LṬ p. 136) : 'śubhāyā Ms.

73 para $<\tan >\operatorname{tra}^{\circ}$ em. (gzhan dbang $\mathrm{T}$ ) : paratra ${ }^{\circ} \mathrm{Ms}$.

74 o[java]t Ms (skyes pa bzhin T).

75 [dh·tu] Ms (gtan tshigs T).
} 
ajñāyamānātmakam apy ajātam

bhāvo yadi syāt paratantrarūpạ̣ |

vandhyāsutenāpakrtaṃ parasya

kiṃ nāma yenāsya na vetti sattvam $\| 6.77$

yadānyatantraṃ na samasti kiṃcit

kiṃ sāṃvṛtānāṃ ${ }^{76}$ hi nibandhanam syāt |

dravyasya lobhena parasya naștāḥ

sarvā vyavasthā api lokasiddhāḥ || 6.78

ācāryanāgārjunapādamārgād

bahirgatānāṃ na śivābhyupāyaḥ |

bhrașțā hi te saṃvṛtitattvasatyāt

tadbhraṃśataś cāsti na mokṣasiddhị̣ $\|^{77} 6.79$

upāyabhūtaṃ vyavahārasatyam

upeyabhūtaṃ paramārthasatyam $\left.\right|^{78}$

tayor vibhāgam na paraiti yo vai

mithyāvikalpaị sa kumārgayātaḥ ${ }^{79}{ }^{80} 6.80$

na saṃvṛtiś cāpi mayābhyupetā

yathā tvayeștạm paratantrarūpam |

lokānurodhāt tv asatīty amīṣāṃ ${ }^{81}$

satīti kāryārtham ahạ̣ bravīmi || 6.81

skandhān samutsṛjya śivapraveśe

yathārhatāṃ nāsti tathaiva na syāt |

lokasya cet tadvad imāṃ satīti

brūyām ahạ̣ naiva hi lokato 'pi || 6.82

niṣidhyatām lokata eva caiṣā

na lokabādhā bhavato yadi syāt

loko bhavāṃś ceha vivādam etu

paścād balīyāṃsam ahaṃ śrayiṣye \| 6.83

vijñānamātram tribhavaṃ paraiti

yad bodhisattvo 'bhimukho 'bhimukhyām |

nityātmakartṛpratiṣedhabodhāt

prapadyate kartṛ sa cittamātram \| 6.84

uktam cāto dhīmatāṃ dhīvivṛddhyai

sarvajñenottungatīrthyādribhedi |

\footnotetext{
76 sā $<m>$ vrtāo em. (kun rdzob pa T) : sāvṛtāo Ms.

77 cf. SS p. 22, saṃvṛtisatyamārgāt for saṃvṛtitattvasatyāt.

78 BCAP p. 179.

79 kumārgayātah em. : kumārggayataḥ Ms.

${ }^{80}$ SS p. 22.

81 amīṣām em. ('di dag T) : madhīšām Ms (Written in the right-hand margin).
} 
sūtre tasminn āryalaṃkāvatāre

sandhyucchittau vānmayạ̣ vajram etat || 6.85

tasmin tasmin varniitāḥ ${ }^{82}$ sāstra ete

tîrthyair yuktyā pudgalādyā yathāsvam |

kartṛtvenāpaśyatā tān jinena

lokasyoktam cittamātraṃ tu kartr || 6.86

buddho yadvad buddhatattvo niruktas

tadval lokaś cittamātrapradhānah |

uktaḥ sūtre cittamātram niṣedho

no rūpasyetīha sūtrārtha evam || 6.87

rūpam eva yadi tatra niṣiddhạ̣

cittamātram idam ity avagamya |

mohakarmajam uvāca kimarthạ̣

cittam atra punar eva mahātmā $\|^{83} 6.88$

sattvalokam atha bhājanalokaṃ

cittam eva racayaty aticitram |

karmajạ̣ hi jagad uktam aśeșaṃ

karma cittam avadhūya ca nāsti $\|^{84} 6.89$

rūpam asti khalu yady api tasya

kartritā tu na hi cittavad asti

tena kartur itarasya hi cittād

vāraṇaṃ na khalu rūpaniședhạ̣ $\| 6.90$

pañcāpy ete santi lokaprasiddhāḥ

skandhās tattve laukike 'vasthitasya |

tattvajñānasyodaye vāñchite ${ }^{85}$ vai

pañcāpy ete yogināṃ naivajātāḥ || 6.91

rūpābhāve mā grahīś cittasattāṃ

rūpābhāvaṃ cittasattve ca mā gāh |

prajñānītau sūtra ete samānaṃ

buddhaị̣ kṣiptā varṇitāś cābhidharme ${ }^{86}$ || 6.92

bhitvāpy etāṃ satyayor ānupūrvīṃ

na dravyạ̣ te yāti siddhị̣ niṣiddham |

tasmād evamprakramād viddhi bhāvān

loke jātāṃs tattvataś cādyajātān \| 6.93

\footnotetext{
82 varṇitā $<$ ḥ $>$ em. : varṇnitā Ms.

83 SS p. 19, adhigamya for avagamya; eșa for eva.

${ }^{84}$ SS p. 19; BCAP p. 52 and p. 222, AKU, p. 117.

85 vāñchite em. ('dod pa T) : vācchite Ms.

86 odharme em. (chos las T) : ${ }^{\circ}$ dharmādișu Ms.
} 
yatrāpy uktam nāsti dṛ́śyạ̣ bahir vai cittạ̣ citrạ̣ dṛ́syate ceti sūtre | rūpe 'tyantạ̣ ye prasaktā badhāna ${ }^{87}$

rūpạ̣ tebhyas tac ca neyārtham ehi ${ }^{88}$ || 6.94

neyārthatvaṃ cādideśāsya śāstā

yuktā yuktyā cāpi neyārthatāsya |

sūtrasyānyasyāpi caivaṃvidhasya

neyārthatvạ̣ dyotayaty āgamo 'yam || 6.95

jñeyạ̣ vinā jñānanirākṛtiś ca

labhyā sukheneti vadanti buddhāḥ

jñeyasya pūrvam pratiședham eva

jñeye'sati jñānaniṣedhasiddheh || 6.96

evaṃ jñātvā prakriyām āgamasya

vyākhyātārthaṃ ${ }^{89}$ yac ca neyārtham uktam |

sūtram buddhvā nīyatāṃ yan ${ }^{90}$ na tattvaṃ

nītārthạ̣ ca jñāyatāṃ śūnyatārtham ${ }^{91}$ || 6.97

dvābhyāṃ na cāpi jananaṃ khalu yuktarūpạ̣

doșāh patanti vihitās tuta eva yasmāt |

na lokato 'pi na ca tattvata ișțam etad

ekaikato na jananasya yato 'sti siddhị || 6.98

hetum vinaiva yadi janma bhavet tadānīṃ

syāt sarvato 'pi sakalasya sadaiva janma |

bījādikasya śataśaḥ phalasambhavāya

lokaś ca saṃgraham ayạ̣ khalu naiva kuryāt ${ }^{92} \| 6.99$

gṛhyeta naiva ca jagad yadi hetuśūnyaṃ

syād yadvad eva gaganotpalavarṇagandhau $\left.\right|^{93}$

gṛhnāsi lokam aticitratarạ̣ ca tasmāl

lokạ̣ svabuddhim iva kāraṇataḥparaihi || 6.100

bhūtāni tāni na hi nāma tathātmakāni ${ }^{94}$

yenātmanā tava dhiyo vișayībhavanti |

atraiva yasya bahulo 'sti mano'ndhakāro

lokạ̣ param sa katham eșyati samyag eva \| 6.101

\footnotetext{
${ }^{87}$ badhāna em. (bzlog pa T) : badhāra Ms.

88 T nyid for ehi.

89 vyākhyātā $<\mathrm{r}>$ tham em. (bshad don can T) : vyākhyātāthaṃ Ms.

90 yan n.e.T.

$91{ }^{\circ} \bar{a}$ rtha $<\mathrm{m}>$ em. : ${ }^{\circ} \bar{a}$ rtha Ms.

$92 \mathrm{ku}<\mathrm{r}>$ yāt em. ('gyur T) : kuyāt Ms.

93 Pras p. 38.

94 T de yi bdag ñid can for tathātmakāni.
} 
jñeyasvabhāvaviparītadṛśam paraihi

svātmānam eva paralokaniṣedhakāle |

taddṛștijātasadṛśāśrayadehavattvād

bhūtātmasattvam upayāsi yadā tadeva \| 6.102

bhūtāni tāni na hi santi yathā tathoktam

sāmānyatạ̣ svaparato dvayataś ca janma |

āhetukaṃ ca khalu yena purā niṣiddham

bhūtāny amūny anuditāni na santi tasmāt $\|^{95} 6.103$

bhāvāḥ svabhāvarahitāḥ svaparobhayasmāj

janmāsti hetum anapekṣya ca naiva yasmād |

mohas tu yena bahalo ghanavrnndatulyo

lokasya tena viṣayāḥ khalu bhānti mithyā $\|^{96} 6.104$

kaścid yathaiva vitathạ̣ timiraprabhāvāt

keśadvicandraśikhicandrakamakṣikādi I

gṛhṇāti tadvad abudhạ̣ khalu mohadoṣād

buddhyā vicitram avagacchati saṃskṛtam hi $\|^{97} 6.105$

moham pratītya yadi karma vinā na mohād

bhūtam tad ity abudha eva pareti nūnam |

sadbuddhibhāskaravihīnaghanāndhakāro

vidvāṃs tu śūnyam avagacchati mucyate ca || 6.106

na tattvataś cet khalu santi bhāvās

teșām asattvaṃ vyavahārato 'pi |

syād eva vandhyātanayasya yadvat

svabhāvatah sattvam ato 'sti teșām || 6.107

keśādayas te na hi nāma jātā

ye taimirāder vișayam prayānti |

ta eva tāvat khalu codanīyāḥ

paścād avidyātimirānujātāḥ || 6.108

svapnaṃ sagandharvapuraṃ marīcyāṃ

kam indrajālaṃ pratibimbakādi |

paśyasy ajātān yadi tat kathạ̣ te

tulye 'py asattvena tu tan na yuktam || 6.109

ete na tattvena yathaiva jātā

na vāpi vandhyāsutavan na yānti |

lokasya yad darśanagocaratvạ̣

tasmād anaikāntikam etad uktam || 6.110

\footnotetext{
95 SS p. 17.

96 SS pp. 17-18.

97 SS p. 18.
} 
svenātmanā janma na tattvato 'sti vandhyāsutasyāpi na lokato 'pi tathāsvabhāvena na lokato 'mī jātā na tattvena ca sarvabhāvāḥ || 6.111

dharmān jagādādita ${ }^{98}$ eva śāntān atah prakṛtyā parinirvṛtāṃś ca | śāstā viyuktān udayena sarvān yatas tato nāsti sad eva janma || 6.112

ghațādayạ santi na tattvato 'mī lokaprasiddhyā tu yathā bhavanti bhāvā bhavișyanti tathaiva sarve ${ }^{99}$ syān naiva ${ }^{100}$ vandhyāsutavatprasañgaḥ || 6.113

ahetutaś ceśvarakāraṇādeh svasmāt parasmāt dvayataś ca yasmād | utpadyamānā na hi santi ${ }^{101}$ bhāvās tasmāt pratītyaprabhavaṃ prayānti || 6.114 pratītyabhāvaprabhavena ${ }^{102}$ śakyā na kalpanāh kalpayitum yad etāḥ | tasmāt pratîtyodayayuktir eșā kudṛștijālaṃ sakalạ̣ chinatti || 6.115 syụ $^{103}$ kalpanā vastuni vidyamāne parīkṣitạ̣ vastu yathā ca nāsti | vinendhanaṃ nāsti yathaiva vahnis tadvad vinā vastu bhavanti naitāḥ || 6.116

yā kalpanānāṃ vinivṛttir etat phalạ̣ vicārasya budhā vadanti | prthagjanāh kalpanayaiva baddhā akalpayan muktim upaiti yogi $\|^{104} 6.117$

na vādalobhād vihito vicāras tattvam tu śāstre kathitạ̣ vimuktyai | vyākhyāyamāne yadi nāma tattve bhidāṃ gatāny anyamatāny adoṣaḥ || 6.118 svadṛțtirāgo 'pi hi kalpanaiva tathānyadṛștāo api yaś ca roṣah |

\footnotetext{
98 jagād $^{\circ}$ em. : jāgad ${ }^{\circ}$ Ms.

99 sa $<\mathrm{r}>$ ve em. (thams cad T) : save Ms.

100 syān nai < va > em. (mi 'gyur T) : syān nai Ms.

101 santi em. (yin pa T) : śanti Ms.

102 obhavena em. ('byung bas T) : 'bhaveva Ms.

103 syuh em. ('gyur ba T) : ‘h Ms.

104 SS p. 20.
} 
vidhūya rāgaṃ pratighạ̣ ca tasmād

vicārayan kṣipram upaiti muktim || 6.119

satkāyadṛștiprabhavān aśeșān

kleśāṃś ca doṣāṃś ca dhiyā vipaśyan |

àtmānam asyā viṣayaṃ ca buddhvā

yogī karoty ātmaniṣedham eva $\|^{105} 6.120$

àtmā tīrthyaih kalpyate nityarūpo

'kartābhoktā nirguno niṣkriyaś ca |

kaṃcit kamcid bhedam āśritya ${ }^{106}$ tasya

bhedam yātāḥ prakriyās tīrthikānām $\|^{107} 6.121$

itthaṃbhūtasyātmano nāsti sattvaṃ

nāhaṃkārasyāśrayaś caișa yuktạ̣ |

vandhyāputrasyeva jāter viyogān

no saṃvṛtyāpīṣyate sattvam asya \| 6.122

śāstre śāstre ye 'sya tīrthyair viśeșā

nirdiśyante tān ajātatvahetur |

yasmāt sarvān bādhate svaprasiddhạ

santy asyāto nāpi sarve viśeșāḥ || 6.123

skandhebhyo 'nyo vidyate nāta ātmā

hitvā skandhāṃs tadgrahasyāprasiddheh ${ }^{108}$ |

lokasyāhaṃkārabuddher apīṣto

naivādhāro 'tadvidām ātmadṛștẹ || 6.124

tiryakto ye kalpaśah sampravṛddhā

nityājātam te 'pi paśyanti nainam |

dṛșțā teșām apy ahaṃkāravrtttiṃ ${ }^{109}$

skandhebhyo ${ }^{110}$ 'nyas tena nātmāsti kaścit $\| 6.125$

skandhā evālambanaṃ tv ātmadṛsțeh

skandhebhyo 'nyasyātmanaḥ siddhyabhāvāt |

skandhān* pañcāpy eka icchanti kecic

cittạ̣ tv ekaṃ niśrayāyātmadṛșțeh || 6.126

skandhā ātmā ced atas tadbahutvād

àtmānaḥ syus te 'pi bhūyāṃsa evam |

\footnotetext{
105 Pras p. 340.

106 āśritya em. (brten nas T) : āśṛtya Ms.

107 Pras p. 344 yātā prakriyā for yātāh prakriyās.

108 ograhasyāprasiddheh em. ('dzin ma grub T) : ' grahasya prasiddheh Ms.

109 ovrttim em. : ${ }^{\circ}$ pravṛttim Ms (hypermetrical).

110 skandhebhyo em. (phung po las T) : svandhebhyo Ms.
} 
dravyạ̣ cātmā prāpnuyāt taddrśśś ca

dravye vṛttau vaiparītyạ̣ ca na syāt $\|^{111} 6.127$

ātmocchedī nirvṛtau syād avaśyạ̣

nāśotpādī nirvṛteh prāk ${ }^{112}$ kṣaṇeșu |

kartur nāśāt tatphalābhāva eva

bhuṃjītānyenārjitaṃ karma cānyaḥ $\|^{113} 6.128$

na syād doṣaḥ santatis tattvataś ced

ukto doșaḥ santateh prāgvicāre |

skandhā nātmā nāpi cittạ̣ ca tasmād ${ }^{114}$

ito $^{115}$ lokasyāntavattvādyabhāvāt || 6.129

ātmābhāvaṃ paśyato yoginaś ca

bhāvābhāvaḥ syādavaśyaṃ tadā te |

nityātmā cet kṣipyate te tadānīm

skandhāś cittạ̣ vā bhaven nāta ātmā $\| 6.130$

rūpādīnāṃ naiva tattvạ̣ gatạ̣ syād

ātmābhāvaṃ paśyato yoginas te

rāgādīnāṃ rūpam ālambya vṛtteh

syād utpattis tatsvarūpāvibodhāt || 6.131

skandhā ātmety uktavān yena śāstā

skandhā evātmeti tasmān mataś ${ }^{116}$ cet |

skandhebhyo 'nyasyātmano 'sau niședho

rūpạ̣ nātmetyādisūtrāntarokteh || 6.132

rūpaṃ nātmā vedanā no na saṃjñā

no saṃskārā nāpi vijñānam uktam |

sūtre 'nyasmin yena tasmān na hīșțạ

skandhā evātmeti sūtropadeśah \| 6.133

skandhā ātmety ${ }^{117}$ ucyamāne samūhah skandhānāṃ syān naiva tu skandharūpah |

no nāthatvaṃ no damaḥ sākṣitā vā

tasyāsattvāt syād ato no samūhaḥ || 6.134

kūṭasthānāṃ syād rathatvaṃ tadānīm tasyāngānāṃ ${ }^{118}$ tulya $\bar{a}^{1} \bar{a}^{\mathrm{i} 19}$ rathena |

\footnotetext{
111 Pras p. 342, eva for evam; tādṛṣaś for taddṛśás.

112 prāk em. : prāka Ms.

113 Pras p. 342, àtmocchedo for ātmocchedī; and nāśotpādau for nāśotpādī.

114 tasmād em. (de'i phyir T) : nna smād Ms.

115 ito em. : itaś ca Ms (hypermetrical); n.e. T.

116 mata $<$ ś $>$ em. : mata Ms.

117 àtmety em. (bdag ces T): ātmāty Ms.

118 tasyā $<\dot{\mathrm{n}}>$ gānām em. (de yi yan lag ... rnams T) : ${ }^{\circ}$ tasyāgānāṃ Ms.

119 tulya ātmā em. : tulyātmā Ms.
} 
skandhāṃś copādāya sūtre niruktas

tasmān nātmā skandhasaṃhātamātram || 6.135

saṃsthānaṃ ced rūpiṇāṃ tasya sattvāt

teșām evātmeti ${ }^{120}$ samjuñā tava syāt |

cittādīnāṃ saṃhater ātmatā tu

na syād yasmāt saṃniveśo 'sti naișām || 6.136

nopādātuś caikatā yuktarūpā

svopādānaị̣ kartṛkarmaikataivam | syāt kartāsan karma cāstīti ced dhīr no kartārạ̣ yad vinā nāsti karma || 6.137

bhūmyambutejāṃsi samīraṇaṃ ca vijñānam ākāśam iti pratītya | dhātūn ${ }^{121}$ șaụ ātmā muninopadișțạ̣ sparśâśrayāṃ ṣaṭ ca sa cakṣurādīm || 6.138

dharmān upādāya sa cittacaittān nirucyate yena tato na tattvam | tebhyo 'sya no saṃhatimātratā ca tasmād ahaṃkāramatir na teṣu || 6.139

nityātmā ca kṣipyate 'nātmabodhe nāhaṃkārasyāśrayaś cāyam iștah | ātmābhāvajñena kiṃ tat ${ }^{122}$ svadṛșter utkhātaś cety ucyate 'tīva citram || 6.140

paśyann ahiṃ chidragatam svagehe gajo 'tra nāstīti nirastaśan̉kaḥ | jahāti sarpād api nāma bhītim aho hi nāmārjavatā parasya $\|^{123} 6.141$ skandheșv ${ }^{124}$ ātmā vidyate naiva cāmī santi skandhā nātmanītīha yasmāt | saty anyatve syād iyam kalpanā vai tac cānyatvaṃ nāsty ${ }^{125}$ atah kalpanaișā $\|^{126} 6.142$ ișto nātmā rūpavān nāsti yasmād ātmā matvarthīyayogohi nātạ̣ |

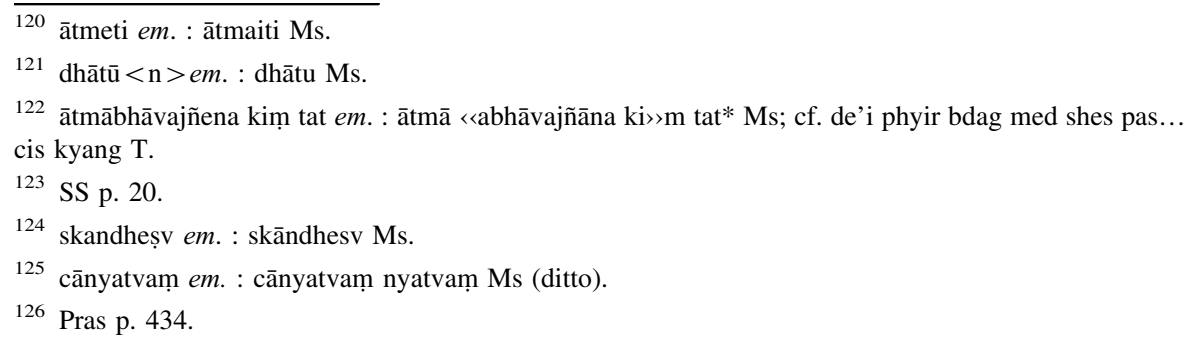


bhede gomān rūpavān apy abhede tattvānyatve rūpato nātmanaḥ ${ }^{127}$ staḥ $\|^{128} 6.143$

rūpạ̣ nātmā rūpavān naiva cātmā rūpe nātmā rūpam ātmany asac ca | skandhān evaṃ ${ }^{129}$ viddhi sarvāṃś caturdhā viṃśaty aṃśā eta iștāḥ svadṛstẹ̣ $\|^{130} 6.144$

etāni tāni śikharāṇi samudgatāni satkāyadṛștivipulācalasaṃsthitāni | nairātmyabodhakuliśena vidāritātmā bhedaṃ prayāti saha tair api dṛșțiśailaḥ $\|^{131} 6.145$

icchanty eke pudgalaṃ dravyasantam tattvānyatvānityanityādyavācyam ${ }^{132} \mid$ șaḍvijñānajñeyatā ceșyate 'sya so ${ }^{133}$ 'hạ̣kārasyāśrayo ${ }^{134}$ hīṣyate ca || 6.146

naivāvācyaṃ vastusat sampratītạ̣ yac cittasyāvācyatāṃ naiși rūpāt | ātmā kaścid vastusiddho yadi syān nāvācyạ̣ syāc cittavat siddharūpạ̣ || 6.147

yaḥ skandhebhyo 'vācyatāṃ yāta ātmā sattvaṃ siddham svātmanā tasya mā gāḥ | vastutvenāsiddharūpo ghațas te rūpādibhyo 'vācyatāṃ yena yātah || 6.148

vijñānaṃ te svātmato 'nanyad ișțạ̣ rūpādibhyo bhinnarūpạ̣ matạ̣ ca | vastuny ete dve gatī nāma dṛște nāsty ātmāto vastudharmair viyogāt || 6.149

nāhaṃkārasyāśrayo vastu tasmān nānyah skandhebhyo 'pi na skandharūpạ̣ | skandādhāro naiva naivaișa tadvān skandhāṃs tūpādāya yāty eșa siddhim || 6.150

svāngebhya ișto na ratho yathānyo na cāpy ananyo na ca nāma tadvān |

\footnotetext{
127 nātmana $<$ h $>$ em. : nātmana Ms.

128 Pras p. 434, mattvārthopayogo for matvarthīyayogo.

129 eva $<$ m $>$ em. (de ltar T) : eva Ms.

130 SS pp. 20-21, caturvimiśaty aṃśā eveștāḥ for caturdhā viṃśaty aṃśā eta ișțạ̄.

131 SS p. 21, sahasaiva tu for sahatair api.

132 tattvānyatvāo $\bar{a}^{\circ}$. (de nyid gzhan nyid T) : [ta]ttvatvānya $\left\langle\right.$ tvā ${ }^{\circ} \mathrm{Ms}$.

133 so em. : șo Ms.

$134<$ '> haṃkārasyāo em. : haṃkarasyāo $\bar{a}^{\circ}$ Ms (The scribe corrects karā to kara.).
} 
nāṅgeșu nāñgāny api tatra nāpi

saṃghātamātraṃ na ca sanniveśạ̣ || 6.151

saṃhātamātram ${ }^{135}$ hi ratho yadi syāt

kūṭasthiteșv eva bhaved rathatvam |

saṃsthānamātram ca ratho na yuktah

santy $^{136}$ angināngānini ${ }^{137}$ vinā na yasmād || 6.152

saṃsthānam añgeșu yathā purābhūt

pratyekaśas te rathatām gateșu |

tathaiva cen nāsti ratho 'dhunāpi

viślișțabhūteșu yathaiva teșu $\| 6.153$

saṃsthānabhedo yadi cādhunāsti ${ }^{138}$

cakrādikasyeha rathatvakāle |

gṛhyeta nāmaișa na caitad asti

saṃsthānamātraṃ na ratho 'sti tasmāt || 6.154

na cāñgavṛndasya sa saṃniveśo

vụndạ̣ na kiṃcit tava yena nāma |

na nāma kiṃcit khalu yat kathaṃ tat

saṃsthānam āśritya bhaviṣyatīha || 6.155

yatheșțam etat tava tadvad eva

hetor asatyasya samāśrayeṇa |

asatyarūpaṃ khalu kāryajātam

utpadyate sarvam apīty avaihi || 6.156

etena rūpādiṣu kumbhabuddhis

tathāsthiteșv ity api naiva yuktam I

rūpādayaś ${ }^{139}$ cāpi na santy ajātās

teșāṃ na saṃsthānam ato 'pi yuktam || 6.157

na tattvato naiva ca lokataś ca

sa saptadhā yady api yāti siddhim |

svāñgāny upādāya vinā vicāraṃ

prajñapyate lokata eva caișah \| 6.158

angī sa evāvayavī ${ }^{140}$ sa kartā

rathah sa eveti jane niruktị |

siddho 'py upādātṛtayā janānāṃ

mā saṃvṛtị̣ nāśaya lokasiddhām || 6.159

\footnotetext{
135 sa $<$ ṃ $>$ hāta $^{\circ}$ em. (cf. tshogs T) : sahāta ${ }^{\circ}$ Ms.

136 santy em. : saty Ms.

137 ○nā < ṅ > gāni em. (yan lag dag T) : ' nāgāni Ms.

138 cādhunāo em. (dus 'dir T) : cāpunāo Ms.

139 rūpādayaś em. (gzugs sogs T) : rūpodayaś Ms.

140 evāvayavī em. (cha śas can T) : evāpayavī Ms.
} 
yaḥ saptadhā nāsti kathaṃ tu sa syād

ity asya sattām labhate na yogī

tattvāvatāro 'pi sukhena vāta

itīṣyatām evam ihāsya siddhị̣ || 6.160

sattvaṃ rathasyāsti ${ }^{141}$ na cet tadānīm

vināngināñāny ${ }^{142}$ api santi nāsya |

dagdhe rathe 'ngāni yathā na santi

dhīvahnidagdhe 'ngini tadvad añgam || 6.161

ātmāpy upādātṛtayā tatheșțạ̣

skandhān upādāya jagatpratītyā |

dhātūṃs tathā cāyatanāni șaḍ̣hāā

karmāpy upādānam asau ca kartā || 6.162

nānityatā cāsya na nityatā ca

na jāyate naśyati naiva cāyam |

na śāsvatatvādi ca vidyate 'sya

tattvạ̣ na cānyatvam avastusattvāt || 6.163

ayaṃ sa ātmā jagatāṃ pravrttāa ${ }^{143}$

yasmin ahamkāramatị sadaiva |

yat tasya tasmin mamakārabuddhir

udeti mohād avicārabuddhyā || 6.164

akartṛkạ̣ karma ca nāsti yasmād

ātmānam ātmīyam ato vinā 'sat |

ātmānam ātmīyam atạ sa śūnyạ̣

paśyan vimuktim samupaiti yogī || 6.165

ghațapațakațasenāḥ kānanaṃ pańktivṛkṣā

gṛhaśakațamațhādyā ye ca kecit padārthāh |

vyavaharati jano 'yaṃ yais tathā tān pratīhi

vivadati sa munīndro yan na lokena sārddham $\| 6.166$

avayavaguṇarāgā lakṣaṇānīndhanādyā

avayavigụiraktā lakṣyam agnyādayo 'rthāḥ |

vihitarathavicārāt saptadhā santi naite

sati tu taditarasmin santi lokaprasiddhyā || 6.167

janayati yadi hetur janyam evam sa hetur

na janayati phalaṃ cet tadvināhetukạ̣ syāt |

phalam api sati hetau jāyate yena tasmāt

kathaya bhavatu pūrvam kiṃ ${ }^{144}$ kuto yad yatah syāt || 6.168

\footnotetext{
141 rathasyā $\bar{a}^{\circ}$ em. : rathāsyā $\bar{a}^{\circ} \mathrm{Ms}$.

142 vinā $<\dot{\mathrm{n}}>\operatorname{gina} \bar{a}^{\circ}$ em. (yan lag can med $\mathrm{T}$ ) : vināgina $\bar{a}^{\circ}$ Ms.

143 pravṛttā em. : pravṛtto Ms.

144 pūrva $<$ ṃ $>$ kiṃ em. : pūrva «kiṃ»» Ms.
} 
janayati yadi hetuh prāpya kāryam tadā te na janakaphalabhedah syāt tayor aikyaśakteh | prithag ayam aviśișto ${ }^{145}$ 'hetubhih syāc ca hetur dvayam idam avadhūyānyāsat̄̄ kalpanā ca || 6.169

phalam atha tava hetur no karotity ato 'sat phalam iti phalahīno 'hetuko san na hetuh ${ }^{146}$ | dvayam idam api māyāsaṃnibhaṃ yena tasmād bhavati na mama doṣo laukikāḥ santi cārthāḥ || 6.170 dūṣyaṃ vidūṣayati ${ }^{147}$ dūṣaṇam āpya caitad aprāpya ceti nanu caișa tavāpi doṣaḥ | svam pakșam eva vinihamsi ${ }^{148}$ vadan yadaivam dūṣyaṃ tadāsi na hi dūṣayitum samarthạ̣ || 6.171

jātyantaraih svavacane 'pi samaprasangair nyāyạ̣ vinā 'pavadase sakalān padārthān | yasmāt tato na khalu sajjanasammmato 'si vaitaṇụiko 'si ca yato 'sti na te svapakṣah || 6.172

aprāpya dūṣayati dūṣaṇam eva yasya prāpyātha dūṣyam iti vā niyamena pakṣaḥ | syāt tasya doṣa udito 'yam ayaṃ tu pakṣo nāstīti naișa mama sambhavati prasangah || 6.173

dṛștā yathā grahaṇakādiṣu te viśeșā àdityamaṇdalagatāh ${ }^{149}$ pratibimbake 'pi | nāprāpya cāpya ca raviṃ pratibimbajātạ̣ yuktam pratītya ca bhaved vyavahāramātram || 6.174

yadvad vyalīkam api tat svamukhopaśobhāsampādane bhavati tadvad ihāpy avaihi | hetoh svasādhyagatam ${ }^{150}$ ity upapattihīnāt prajñāmukhoparacanaṃ prati dṛșțaśakteh || 6.175

prāptyādiyuktyupanayo ${ }^{151}$ hi bhaved yadi syād dhetụ̣ $^{152}$ svasādhyagamakah khalu vastusiddhạ̣ $^{153}$ |

\footnotetext{
145 aviśișto em. (tha dad med gyur T) : avaśișțo Ms.

146 hetuh em.: hetoh Ms.

147 vidūṣayati em. ('byin T) : dūvișayati Ms.

148 vinihamsi em. ('joms pa T) : vinihinsi Ms.

149 'maṇda < la $>{ }^{\circ}$ em. (dkyil 'khor T): ' maṇụa ${ }^{\circ}$ Ms.

150 osādhyagatam em. (cf. bsgrub bya rtogs T): ${ }^{\circ}$ sā/// [gatam] Ms.

$151{ }^{\circ} \bar{a}$ [diyuktyupanayo] Ms (cf. la sogs rigs pa nye bar sbyor bar T; LṬ p. 159 upanayah).

$152{ }^{\circ}[\mathrm{d}$ dhe]tuh Ms (cf. gtan tshigs T).

153 [vastu] ${ }^{\circ}$ Ms (cf. dngos T).
} 
sādhyasvarūpam api vastuta eva gamyam

etac ca nāsti ${ }^{154}$ tava kevalam eva khedah $\| 6.176$

nirvastukā gamayitum sakalāḥ padārthāḥ

śakyā ${ }^{155}$ yathātisukaram na tathā svabhāvaḥ |

śaktah sukhena ${ }^{156}$ khalu bodhayitum pareșām

lokạ̣ $^{157}$ kim anga $^{158}$ lapasīha kutarkajālam ${ }^{159}$ || 6.177

śeșaṃ ca dūṣaṇam avetya puropadișțam

prāptyādipakșaparihārakṛte 'tra dehi |

vaitaṇdikatvam api nāsti yathā tathoktam ${ }^{160}$

prāg eva śeșam avagaccha diśānayaiva || 6.178

nairātmyam etad ${ }^{161}$ dvividham niruktam

dharmātmabhedena jagadvimuktẹ ${ }^{162}$ |

tad eva bhitvā bahuśo 'pi bhūyas

tathā vineyebhya uvāca śāstā || 6.179

śūnyatāḥ ${ }^{163}$ ṣoḍaśākhyāya saprapañcāḥ ${ }^{164}$ samāsatạ̣ |

catasrạ̣ punar ākhyātā mahāyāne ${ }^{165}$ ca tā matāḥ || 6.180

cakṣur vai cakṣuṣā śūnyam asyaișā prakṛtir yataḥ |

evạ̣ śrotram mano jihvā ghrāṇạ̣ kāyaś ca kathyate || 6.181

akūṭasthāvināśitvam upādāyāsvabhāvatā |

yā șaṇnāṃ cakṣurādīnāṃ sā matā 'dhyātmaśūnyatā || 6.182

rūpạ̣ rūpeṇa vai śūnyam asyaișā prakṛtir yataḥ |

evạ̣ śabdā rasā gandhā dharmāḥ sprașțavyam eva ca || 6.183

rūpāder niḥsvabhāvatvaṃ ${ }^{166}$ bahirdhāśūnyatā matā

ubhayor asvabhāvatvaṃ bahirdhādhyātmaśūnyatā $\|^{167} 6.184$

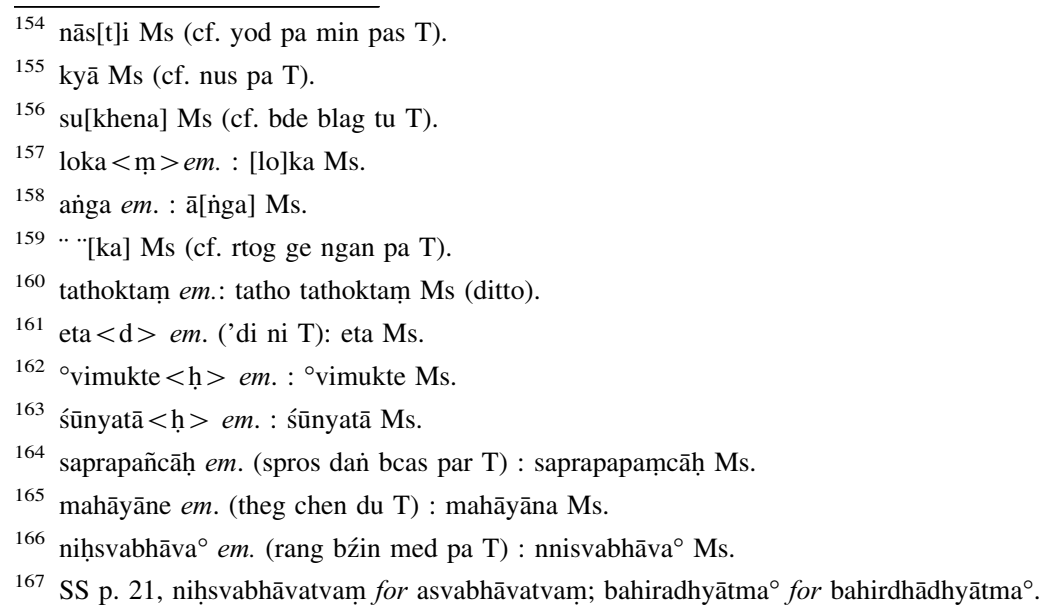


dharmāṇām niḥsvabhāvatvaṃ śūnyatety ucyate budhaih | sā cāpi śūnyatā śūnyā śūnyatārūpato matā $\| 6.185$

śūnyatā sūūyatākhyā yā śūnyatāśūnyatā matā | śūnyatā bhāvabuddhīnām uktā grāhanivṛttaye || 6.186

sattvabhājanalokasya niḥśeșavyāpakatvatạ̣ | apramāṇopamānena paryantābhāvato diśām || 6.187

mahattvạ̣ digbhir evāsāṃ daśānām api śūnyatā | yā mahāśūnyatā soktā mahāgrāhanivṛttaye \| 6.188

paramārtho hi nirvāṇaṃ param etat prayojanam | tasya yā śūnyatā tena ${ }^{168}$ sā paramārthaśūnyatā || 6.189 nirvāṇe bhāvabuddhīnāṃ bhāvagrāhanivṛttaye | deśitân $^{169}$ paramārthajñaị śūnyatā pāramārthikāa || 6.190 dhātutrayaṃ niruktam vai saṃskṛtam pratyayodayāt | tasya yā śūnyatā tena soktā saṃskṛtaśūnyatā || 6.191 asaṃskṛtaṃ na yasyaitā utpādasthityanityatāḥ | tena $\mathrm{ya}^{170}$ śūnyatā tasya soktā 'saṃskṛtaśūnyatā || 6.192 anto na vidyate yasya tad atyantam nirucyate | tasya tenaiva śūnyatvaṃ kathyate 'tyantaśūnyatā || 6.193 ādir avaram anto 'gram tadabhāvena kathyate | saṃsāro 'navarāgro hi gatyāgativiyogatah ${ }^{171}$ || 6.194

svapnābhasya bhavasyāsya yā tenaiva viyuktatā | śūnyatānavarāgreti saișā śāstre nirucyate \| 6.195

avakāro 'vakiraṇaṃ choraṇạ̣ hi nirucyate | na tyāgo 'navakāras tu choraṇaṃ yan na kasyacit || 6.196 tenaivānavakāreṇa yā tasyaiva hi śūnyatā | śūnyatānavakārākhyā tasmād eșā nirucyate || 6.197

śikṣaih pratyekabuddhaiś ca bodhisatvais tathāgataị̣ | svabhāvaḥ saṃskṛtādīnāṃ yato naiva kṛtas tatạ̣ || 6.198 svabhāvaḥ saṃskṛtādīnām prakṛtitvena ${ }^{172}$ kathyate | tayaiva śūnyatā tasyā yā sā prakṛtiśūnyatā || 6.199

\footnotetext{
168 tena em. : yena tena Ms (yena n.e. T).

169 deśitā em. (bstan pa T) : dedeśitā Ms.

170 tena yā suunyatā em. : tena yā śūnyatā tena yā suunyatā Ms (ditto).

171 gatyāgati ${ }^{\circ}$ em. ('gro 'ong T) : gatyāgatti ${ }^{\circ} \mathrm{Ms}$.

172 prakrtitvena em. : prakṛtitveda Ms.
} 
dhātavo 'ștāasaśa sparśāḥ șaṭ tajjā vedanāś ca șaṭ | rūpiṇo 'rūpiṇo dharmāḥ saṃskṛtāsaṃskṛtās tathā | 6.200

śūnyatā sarvadharmāṇām yā teșāṃ tair viyuktatā | rūpaṇāder abhāvo yaḥ sā svalakṣaṇaśūnyatā || 6.201

rūpaṇālakṣaṇaṃ rūpaṃ vedanānubhavātmikā ${ }^{173}$ | nimittodgrahạ̣ạ̣ saṃjñā saṃskārās tv abhisaṃskṛtị̣ || 6.202 vișayạ̣ prati vijñaptir vijñānasya svalakṣaṇam | duhkhhasvalakṣaṇāḥ skandhā dhātvātmāśsiviș̣aṃ matam || 6.203

āyadvāratayoktāni buddhair āyatanāni ca | yaḥ pratītyasamutpādạ̣ sa sāmagrīsvalakșaṇaḥ || 6.204

dānapāramitā tyāgạ̣ śîlạ̣ cādāhalakșaṇam | akopalakșaṇā kṣāntị̣ vīryasya tv anavadyatā || 6.205

saṃgrahalakṣaṇaṃ dhyānaṃ prajñā cāsañgalakṣaṇā | ṣaṇnāạ pāramitānāṃ vai lakṣaṇaṃ kathitaṃ tv idam || 6.206

dhyānāni cāpramāṇāni ye cārūpyāśs ${ }^{174}$ tathā pare akopalakṣaṇā eta uktāḥ samyakprajānatā || 6.207 saptatriṃśad ${ }^{175}$ bodhipakșyā nairyāṇikasvalakṣaṇāḥ ${ }^{176}$ | śūnyatāyā viviktatvaṃ lakṣaṇaṃ nopalambhanāt || 6.208 śāntatā tv animittasya duḥkhāmohas ${ }^{177}$ tu lakṣaṇam | tṛtīyasya vimokṣāṇāṃ lakṣaṇaṃ tu vimocanam || 6.209

suviniścitarūpāṇi balāni kathitāni ca | supratișṭhitarūpāṇi vaiśāradyāni tāyinaḥ || 6.210

pratibhānādyanācchedalakṣaṇāḥ pratisamividaḥ | jagaddhitopasaṃhāro mahāmaitrī nirucyate || 6.211 mahākṛpā paritrāṇaṃ duhkhināṃ muditā khalu | prāmodyalakṣaṇopekșân $^{178}$ jñeyāsaṃkīrṇalakșaṇā ${ }^{179}$ || 6.212 buddhasyāveṇikā dharmā daśa cāșțau ca ye matāh | tair ahāryo yataḥ śāstā tato 'hāryasvalakșaṇāḥ || 6.213

\footnotetext{
173 vedanānubhavā em. (tshor ba myon ba T) : vedanā anubhāva Ms.

174 cārūpyāśs em. : cārupyāś Ms.

$175{ }^{\circ}$ tri $<$ ṃ $>$ śad em. (sum cu T) : triśad Ms.

176 nairyāṇikasvalakṣaṇā $<$ ḥ $>e m$. (nges par 'byung byed rang mtshan nyid T) : nairyānikṣasvalakṣaṇā Ms.

177 ○mohas em. (gti mug med T) : ${ }^{\circ}$ mauhaus Ms.

178 olakșaṇopekșā em. : 'lakșaṇā upekșa Ms.

179 jñeyāsa $<m$ mīnna ${ }^{\circ}$ em. (ma 'dres....shes bya ba T) : jñēyāsakīrṇṇa ${ }^{\circ}$ Ms.
} 
sarvākārajñatājñānaṃ matạ̣ pratyakṣalakṣaṇam |

anyat prādeśikatvena na pratyakṣam itīṣyate || 6.214

yal lakṣaṇaṃ saṃskṛtānāṃ yac cāsaṃskṛtalakṣaṇam ${ }^{180}$

tasya tenaiva śūnyatvaṃ sā svalakṣaṇaśūnyatā || 6.215

asthito vartamāno 'yam atītānāgatam na sat |

yatraite nopalabhyante 'nupalambhah sa ucyate || 6.216

yā tasyānupalambhasya tatsvarūpaviyuktatā

sākūṭasthāvināśenānupalambhākhyaśūnyatā ${ }^{181}$ || 6.217

nāsti sāṃyogikaṃ rūpaṃ bhāvānāṃ ${ }^{182}$ pratyayodayāt

saṃyogasya tu tenaiva śūnyatābhāvaśūnyatā || 6.218

ucyante bhāvaśabdenapañcaskandhāḥ ${ }^{183}$ samāsatạ̣ |

tair eva ${ }^{184}$ śūnyatā teșāṃ yā soktā bhāvaśūnyatā || 6.219

abhāvo 'saṃskrtā dharmā nirdiśyante samāsatạ̣ |

tenābhāvena śūnyatvạ̣ tasyaivābhāvaśūnyatā || 6.220

prakṛter niḥsvabhāvatvaṃ svabhāvākhyā tu śūnyatā |

prakṛtir na kṛtety evaṃ svabhāva iti kathyate || 6.221

utpāde 'pi hi buddhānām anutpāde 'pi bhāvatạ̣ |

śūnyatā sarvabhāvānāṃ paro bhāvaḥ prakīrtitạ̣ || 6.222

bhūtakoțis $^{185}$ tathātvaṃ ca ${ }^{186}$ sā parabhāvaśūnyatā ${ }^{187}$ |

prajñāpāramitānītāv ity etāḥ samprakīrtitāḥ ${ }^{188}$ || 6.223

iti matikiraṇasphuṭāvabhāsaḥ

svakaragatāmalakaṃ yathaiva buddhvā |

tribhavam idam aśeșam ādyajātam

vyavahṛtisatyavaśān nirodham eti || 6.224

janayati karuṇāṃ jagaty anāthe

bhavati nirodhagatāśayaḥ sadaișạ̣

jayati ca sakalān dhiyāta ūrdhvạ̣

sugatavacaḥ prabhavāt sa madhyabuddhān || 6.225

\footnotetext{
180 cāsa $<\mathrm{m}>\operatorname{skrta}^{\circ} \mathrm{em}$. ('dus ma byas...dang T) : cāsaskrta ${ }^{\circ} \mathrm{Ms}$.

181 sākū <ṭa $>$ sthā em. (ther zug gnas T) : sākūsthā $\bar{a}^{\circ}$ Ms.

182 bhāvānām em. : bhāvanām Ms.

$183 \mathrm{~Pa}<\tilde{\mathrm{n}}>\mathrm{ca}^{\circ}$ em. (lnga rnams T) : paca $^{\circ} \mathrm{Ms}$.

184 tair eva em. : tair aiva Ms.

$185{ }^{\circ}$ kotis em. : kotīs Ms.

186 ca em. (dang T) : sā Ms.

187 parabhāvaśūnyatā em. (gzhandngos po'i stong nyid do T) : parabhāvāśūnyatā Ms.

188 okīrttitā $<$ h $>$ em. : ${ }^{\circ}$ kīrttitā Ms.
} 
jinaguṇajaladheh paraṃ sa pāraṃ

vrajati puraskṛta eșa janmihamsaih |

śubhapavanabalena rājahamsạ̣

pṛthusitasaṃvṛtitattvajātapakșaḥ $^{189}$ || 6.226

Open Access This article is distributed under the terms of the Creative Commons Attribution License which permits any use, distribution, and reproduction in any medium, provided the original author(s) and the source are credited.

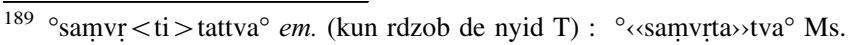

